\title{
Kelakuan Pengoksidaan Keluli Tahan Karat Berferit SUS430 dan Kesan Pemeruapan Spesies Cr Bergas kepada Permukaan Katod LSCF dalam Suhu Operasi Sel Fuel Oksida Pepejal
}

(Oxidation Behaviour of SUS430 Ferritic Stainless Steel and Effects of Gaseous Cr Species Volatilization on LSCF Cathode Surface in Solid Oxide Fuel Cell Operating Temperature)

\author{
ISYRAF AZNAM, JoElle MAH CHIA WEN, ANDANASTUTI MUCHTAR*, NURUl AKIDAH BAHARUdDIN, \\ MAHENDRA RAO SOMALU \& MARIYAM JAMEELAH GHAZALI
}

ABSTRAK

Pengoksidaan antarahubung berasaskan bahan keluli tahan karat SUS430 dalam sel fuel oksida pepejal (SFOP) bersuhu sederhana menyumbang kepada pembentukan lapisan oksida yang mengandungi spesies kromium (Cr) meruap (volatile Cr species) di sekeliling komponen tersebut. Bagi tempoh operasi yang panjang, pemeruapan spesies Cr ini menyebabkan keracunan kromium pada komponen katod yang bersentuhan dengan permukaan antarahubung SUS430. Sehingga kini, katod $\mathrm{La}_{0.6} \mathrm{Sr}_{0.4} \mathrm{Co}_{0.2} \mathrm{Fe}_{0.8} \mathrm{O}_{3-\delta}(\mathrm{LSCF})$ merupakan calon terbaik bagi katod SFOP bersuhu sederhana. Justeru, kajian ini bertujuan untuk mengenal pasti kesan jangka panjang pengoksidaan keluli SUS430 terhadap pembentukan spesies Cr meruap dan menentukan pengaruh pemeruapan Cr ke atas prestasi komponen katod LSCF. Hasil kajian menunjukkan bahawa pengoksidaan keluli SUS430 selama 200 jam membawa kepada pertambahan berat secara parabolik yang berkait dengan mekanisme pertumbuhan sisik oksida. Sisik ini terdapat dua lapisan iaitu spinel di bahagian atas diikuti lapisan kromia dan dilihat tidak memberi kesan signifikan pada kekonduksian SUS430. Walau bagaimanapun, pengendapan Cr pada permukaan katod LSCF menyebabkan pertumbuhan hablur $\mathrm{SrCrO}_{4}$ dan $\mathrm{Cr}_{2} \mathrm{O}_{3}$. Pembentukan tersebut bukan sahaja mengurangkan aktiviti pemangkinan seperti penurunan oksigen dan meningkatkan rintangan elektrik, malah meningkatkan tenaga pengaktifan akibat peningkatan kepekatan kekosongan oksigen. Justeru, penghadangan pemeruapan Cr terbukti amat penting untuk mengekalkan kestabilan jangka panjang SFOP bersuhu sederhana.

Kata kunci: Antarahubung; Fe-Cr; mendakan; peracunan Cr; sisik oksida

ABSTRACT

Oxidation of ferritic stainless steel SUS430-based interconnects in intermediate temperature solid oxide fuel cell (IT-SOFC) contributes to the formation of oxide scales containing volatile chromium $(\mathrm{Cr})$ species around the component. In a longterm operation, $\mathrm{Cr}$ volatilization causes Cr poisoning on the cathode component, which is in contact with the SUS430 interconnect. $\mathrm{La}_{0.6} \mathrm{Sr}_{0.4} \mathrm{Co}_{0.2} \mathrm{Fe}_{0.8} \mathrm{O}_{3-\delta}(\mathrm{LSCF})$ cathode is currently the best candidate for IT-SOFC cathode. This study aims to determine the effects of the long-term oxidation of SUS430 steel on volatile Cr species formation and to investigate the influence of $\mathrm{Cr}$ volatilization on the LSCF cathode performance. The results show that the oxidation of SUS430 steel for 200 h parabolically increased its weight due to oxide scale formation. The scale consists of two layers, namely, the spinel on top and the chromia layer, which does not affect the SUS430 conductivity. However, Cr deposition on the LSCF cathode surface causes the formation of $\mathrm{SrCrO}_{4}$ and $\mathrm{Cr}_{2} \mathrm{O}_{3}$ crystallites. This phenomenon reduces the catalytic activity and increases the electrical resistance and the activation energy due to the high amount of oxygen vacancies. Therefore, the mitigation of volatile Cr species is important in maintaining the long-term stability of IT-SOFCS.

Keywords: Cr poisoning; $\mathrm{Fe}$-Cr; interconnect; oxide scales; precipitation

\section{PENGENALAN}

Sel fuel oksida pepejal (SFOP) merupakan sumber tenaga alternatif yang mesra alam dan menyakinkan kerana ia menukar udara dan fuel (hidrogen) kepada tenaga elektrik melalui tindak balas elektrokimia tanpa proses pembakaran. Namun, perkembangan aplikasi SFOP telah dihadkan oleh kos pembuatan dan suhu operasinya yang tinggi (Baharuddin et al. 2014; Mahmud et al. 2017; Rahman et al. 2010). Dalam usaha untuk mengatasi masalah tersebut, bahan yang mempunyai kekonduksian ion yang tinggi pada suhu lebih rendah $\left(600 \mathrm{ke} 800^{\circ} \mathrm{C}\right)$ telah dikaji dan dibangunkan untuk komponen elektrolit, katod dan anod (Anwar et al. 2017; Baharuddin et al. 2017; Raharjo et al. 2012). Penurunan suhu ini juga membuka peluang kepada para penyelidik untuk menggunakan bahan yang lebih baik dan murah berbanding seramik seperti logam aloi sebagai antarahubung SFOP (Mah et al. 2017). Antarahubung mempunyai dua fungsi utama iaitu mengalirkan elektrik antara sel tunggal dan mengelakkan pencampuran antara fuel dan oksidan masing-masing 
melalui anod dan katod (Irshad et al. 2016). Justeru, bagi membolehkan antarahubung berasaskan logam aloi dapat berfungsi dengan stabil, beberapa kriteria utama perlu dipenuhi.

Jangka hayat SFOP perlu mencecah sehingga 40000 jam untuk digunakan dalam sesuatu aplikasi (Linder et al. 2013; Zeng et al. 2014). Oleh yang demikian, bahan untuk antarahubung mempunyai kriteria yang ketat seperti pekali pengembangan terma (TEC) yang sepadan dengan komponen anod dan katod, kekonduksian elektrik, haba dan rintangan pengoksidaan yang bagus (Qi et al. 2015). Berdasarkan kajian lepas (Hosseini et al. 2016), logam yang mengandungi alumina atau kromium adalah calon yang berpotensi kerana dapat memenuhi kriteria yang diperlukan. Namun, kandungan alumina menyebabkan pertumbuhan lapisan alumina oksida pada suhu yang tinggi. Lapisan ini membawa kepada peningkatan rintangan elektrik menjadikan ia tidak sesuai untuk aplikasi SFOP. Oleh itu, logam yang mengandungi kromium menjadi calon yang dipilih kerana mempunyai sifat pertumbuhan lapisan sisik oksida yang dapat menghalang pertumbuhan alumina, mengurangkan pengoksidaan dengan berkesan dan berkebolehan untuk mengalirkan elektrik (Shaigan et al. 2010).

Bahan logam mengandungi kromium yang berpotensi untuk digunakan adalah $\mathrm{Fe}-\mathrm{Cr}$ dan $\mathrm{Ni}-\mathrm{Cr}$. Antara semua bahan-bahan tersebut, $\mathrm{Fe}-\mathrm{Cr}$ atau nama lainnya keluli tahan karat berferit (FSS) mempunyai kelebihan seperti kandungan kromium optimum, kos pembuatan yang murah dan pembuatan yang lebih mudah (Wu \& Liu 2010). Walau bagaimanapun, apabila terdedah pada suhu operasi SFOP yang lama, berlaku pertumbuhan sisik oksida yang pantas dengan ketebalan mencecah ribuan mikrometer. Pertumbuhan sisik ini mengakibatkan perkecaian kerana ketidaksepadanan TEC dengan komponen SFOP yang lain (Hosseini et al. 2014). Sisik oksida ini mempunyai dua lapisan iaitu kromia $\left(\mathrm{Cr}_{2} \mathrm{O}_{3}\right)$ dan spinel $(\mathrm{Mn}, \mathrm{Cr})_{3} \mathrm{O}_{4}$ dengan keduanya menyumbang kepada pemeruapan spesies $\mathrm{Cr}$ bergas seperti gas kromium oksida $\left(\mathrm{CrO}_{3}\right)$ dan kromium oksihidroksida $\left(\mathrm{CrO}_{2}(\mathrm{OH})_{2}\right)$ (Sachitanand et al. 2013). Gas tersebut boleh terendap pada sempadan tiga fasa (TPB) menyebabkan keracunan $\mathrm{Cr}$ pada katod akibat penghadangan kawasan aktif (Fergus 2005; Hua et al. 2010; Zhu \& Deevi 2003). Keracunan Cr membawa kepada pertumbuhan lapisan tidak aktif mengandungi hablur $\mathrm{SrCrO}_{4}$ dan $\mathrm{Cr}_{2} \mathrm{O}_{3}$ yang menurunkan kekonduksian ion dan aktiviti pemangkinan katod. Walaupun risiko ini telah diketahui, namun perbincangan terperinci mengenai kelakuan pertumbuhan sisik oksida pada permukaan antarahubung FSS dan pengaruhnya kepada pengendapan spesies $\mathrm{Cr}$ bergas pada permukaan katod masih kurang diperincikan. Oleh itu, kajian ini memberi fokus kepada hubung kait kedua fenomena tersebut dengan menggunakan keluli tahan karat berferit SUS430 dan katod berasaskan $\mathrm{La}_{0.6} \mathrm{Sr}_{0.4} \mathrm{Co}_{0.2} \mathrm{Fe}_{0 .} 8 \mathrm{O}_{3-\delta}$ ( $\mathrm{LSCF}$ ), yang merupakan bahan yang lazim digunakan dalam bidang penyelidikan SFOP.

\section{BAHAN DAN KAEDAH}

BAHAN

\section{Antarahubung Keluli Tahan Karat Berferit SUS430}

Dalam kajian ini, substrat antarahubung keluli tahan karat berferit SUS430 komersial telah digunakan dan mempunyai komposisi kimia seperti yang diberikan dalam Jadual 1. Sampel dipotong kepada ukuran 15 $\mathrm{mm} \times 15 \mathrm{~mm}$ dengan ketebalan $1 \mathrm{~mm}$. Setiap sampel digilap dengan kertas pasir 600,800 dan 1200 grit untuk mendapatkan permukaan yang licin dan dibersihkan menggunakan etanol.

Katod $\mathrm{La}_{0.6} \mathrm{Sr}_{0.4} \mathrm{Co}_{0.2} \mathrm{Fe}_{0.8} \mathrm{O}_{3-4}$

Serbuk komersial $\mathrm{La}_{0.6} \mathrm{Sr}_{0.4} \mathrm{Co}_{0.2} \mathrm{Fe}_{0.8} \mathrm{O}_{3}$ (LSCF) dengan ketumpatan $5 \sim 10 \mathrm{~m}^{2} / \mathrm{g}$ telah dibekalkan oleh KCeraCell. Pelet LSCF berdiameter $20 \mathrm{~mm}$ dihasilkan melalui kaedah penekanan dengan beban mampatan $50 \mathrm{MPa}$ menggunakan pemampat hidraulik ekapaksi (Carver, USA). Seterusnya, pelet LSCF disinter pada suhu $1350^{\circ} \mathrm{C}$ dalam udara selama 2 jam dengan kadar kenaikan suhu $5^{\circ} \mathrm{C} / \mathrm{min}$ (Muhammed et al. 2018). Diameter pelet LSCF didapati berkurang kepada $18 \mathrm{~mm}$ dengan ketebalan 1.32 mm selepas persinteran. Pelet LSCF ini disediakan bagi pengujian pemeruapan $\mathrm{Cr}$ dan kekonduksian DC.

\section{ANALISIS KESAN PENGOKSIDAAN JANGKA PANJANG KE ATAS SUBSTRAT ANTARAHUBUNG SUS430}

\section{Pembentukan Lapisan Sisik Oksida pada Substrat} Antarahubung SUS430

Pengoksidaan sampel dilakukan menggunakan relau tiub tegak (VSTF35-1100). Suhu yang digunakan adalah $800^{\circ} \mathrm{C}$ dan dikekalkan sehingga 500 jam dalam udara. Berat sampel sebelum dan selepas pengoksidaan telah ditimbang setiap 50 jam menggunakan mesin penimbang berat (ketepatan $=0.01 \mathrm{mg}$ ). Perubahan berat yang diperoleh menunjukkan berlakunya pembentukan lapisan oksida yang mengandungi spesies $\mathrm{Cr}$ meruap. Pengesahan pembentukan spesies $\mathrm{Cr}$ meruap di atas permukaan substrat antarahubung SUS430 dilakukan melalui pencirian fasa dan mikrostruktur. Pencirian fasa melibatkan analisis pembelauan sinar-X (XRD) (Shimadzu XRD-6000, D8-Advance, Bruker, Germany) dengan radiasi $\mathrm{CuK} \alpha(\lambda=0.15418 \mathrm{~nm})$ dan sudut $2 \theta$ dari $10^{\circ}$ ke $80^{\circ}$. Seterusnya, pencirian mikrostruktur dilakukan menggunakan alur ion fokus mikroskop imbasan elektron pancaran medan (FIB-FESEM) (Oxford Instrumental) tergabung spektroskop penyerakan tenaga sinar-X (EDX).

\section{Perubahan Kekonduksian Elektrik Substrat Antarahubung} SUS430

Pengukuran kekonduksian elektrik substrat antarahubung SUS430 teroksida telah dijalankan dengan menggunakan teknik van der Pauw (Van Herle et al. 1994)were obtained 
from commercial sources: (i seperti yang ditunjukkan dalam Rajah 1. Empat titik persentuhan A-B-C-D disusun dengan geometri empat segi tepat berukuran $10 \times 10 \mathrm{~mm}^{2}$ serta arus malar, $I_{c c}=0.5$ A dialirkan. Empat hingga enam bacaan diambil dan purata turunan voltan, telah dihitung. Nilai rintangan, $R_{S}$ dan pengaliran elektrik masing-masing telah dihitung menggunakan (1) dan (2).

$$
\begin{gathered}
R_{S}=\frac{\pi R}{\ln (2)} \\
\sigma_{D C}=\frac{1}{R s . l}
\end{gathered}
$$

Persamaan (1) adalah ringkasan yang telah dibuat daripada persamaan asal yang telah diperincikan dalam kajian sebelum ini (Van Herle et al. 1994). Nilai $R$ adalah rintangan yang dihitung melalui persamaan $\frac{V_{a v e}}{I_{c c}}$. Manakala $l$ dalam (2) adalah ketebalan plat FSS yang digunakan.

\section{ANALISIS KESAN PEMERUAPAN Cr KE ATAS} PRESTASI KATOD LSCF

\section{Pengendapan Cr ke Atas Katod LSCF}

Katod LSCF (pelet) diapit bersama dengan substrat antarahubung SUS430 dan diletakkan di dalam relau tiub serta dipanaskan pada $800^{\circ} \mathrm{C}$ selama 200 jam membolehkan pemeruapan $\mathrm{Cr}$ daripada lapisan oksida berlaku. Untuk mengenal pasti kelakuan pengendapan Cr kepada katod LSCF, analisis menggunakan FESEM tergabung EDX dan XRD telah dilakukan ke atas permukaan katod sebelum dan selepas ujian pemeruapan $\mathrm{Cr}$.

\section{PERUBAHAN KEKONDUKSIAN}

\section{Elektrik dan Ionik Katod LSCF}

Untuk melihat kesan keracunan $\mathrm{Cr}$ ke atas permukaan katod, kekonduksian elektronik empat titik DC pelet LSCF telah diukur menggunakan teknik van der Pauw daripada suhu $300^{\circ} \mathrm{C}$ ke $800^{\circ} \mathrm{C}$ sebelum dan selepas 200 jam pendedahan kepada bahan SUS430. Selain itu, plot Arrhenius disediakan untuk melihat perubahan pada kekonduksian ion dan tenaga pengaktifan katod LSCF.

\section{HASIL DAN PERBINCANGAN}

\section{PENGOKSIDAAN JANGKA PANJANG KE ATAS SUBSTRAT} ANTARAHUBUNG SUS430

\section{Pembentukan Lapisan Sisik Oksida pada Substrat Antarahubung SUS430}

Rajah 2(a) menunjukkan pertambahan berat sampel meningkat dengan mendadak sehingga tempoh tertentu kemudian semakin perlahan apabila tempoh pengoksidaan meningkat. Hal ini berkait rapat dengan proses pertumbuhan sisik oksida yang berlaku pada permukaan sampel SUS430 seperti yang ditunjukkan dalam Rajah 2(b). Berdasarkan puncak belauan XRD pada Rajah 2(c), didapati bahawa $\mathrm{Mn}, \mathrm{Fe}$ dan $\mathrm{Cr}$ masing-masing teroksida kepada $\mathrm{MnO}$ (PDF 01-071-0636), FeO (PDF 01-074-6141) dan CrO (PDF 00-032-0265) pada awal pengoksidaan melalui penyerapan ke dalam oksigen (Gan et al. 2018; RanjbarNouri et al. 2018). Antara oksida ini, MnO merupakan oksida yang menggalakkan penyerapan permukaan dengan menyediakan laluan penyerapan untuk $\mathrm{Cr}$ dan membentuk lapisan sisik spinel ( $\mathrm{Mn}, \mathrm{Cr})_{3} \mathrm{O}_{4}$ (PDF 01-0795333) (Tucker et al. 2006). Penurunan pertambahan berat sampel sUS430 apabila masa pengoksidaan meningkat kepada 100 jam berkemungkinan berlaku akibat kesemua oksida termasuk $\mathrm{MnO}$ semakin menghilang seperti yang ditunjukkan dalam keputusan EDX. Hal ini, menyebabkan laluan untuk penyerapan $\mathrm{Cr}$ semakin berkurang membawa kepada pertumbuhan perlahan sisik spinel $(\mathrm{Mn}, \mathrm{Cr})_{3} \mathrm{O}_{4}$.

Rajah 3(a) menunjukkan keratan rentas sisik oksida dengan ketebalan $3.44 \mu \mathrm{m}$ pada permukaan SUS430 selepas pengoksidaan 200 jam. Berdasarkan pemerhatian, berlaku retakan dan wujud liang pada antara muka lapisan sisik oksida dan permukaan SUS430 akibat permukaan yang tidak rata seperti yang telah dijangka. Retakan dan liang yang wujud pada antara muka tersebut mencadangkan kemungkinan perkecaian akan berlaku jika tempoh pengoksidaan adalah lebih lama seperti yang dilaporkan dalam kajian Brylewski et al. (2014). Berdasarkan keputusan pemetaan EDX, didapati sisik oksida ini mempunyai dua lapisan iaitu spinel $(\mathrm{Mn}, \mathrm{Cr})_{3} \mathrm{O}_{4}$ dan kromia $\mathrm{Cr}_{2} \mathrm{O}_{3}$ dengan kromia adalah punca penghasilan liang akibat pertumbuhan yang tidak rata (Brylewski et al. 2014). Kajian You et al. (2018) melaporkan perkara ini dapat dihalang secara berkesan dengan penggunaan

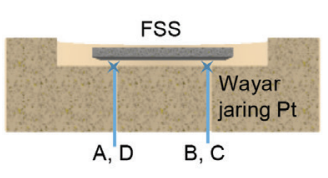

(a)

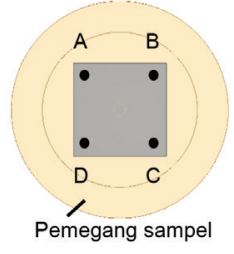

(b)

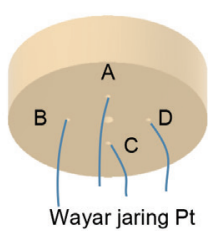

(c)

RAJAH 1. Ilustrasi skematik teknik van der Pauw dari sudut pandangan: (a) keratan rentas; (b) atas; (c) bawah. Pemegang sampel mempunyai empat lubang yang disambungkan dengan wayar jaring platinum (Pt) 

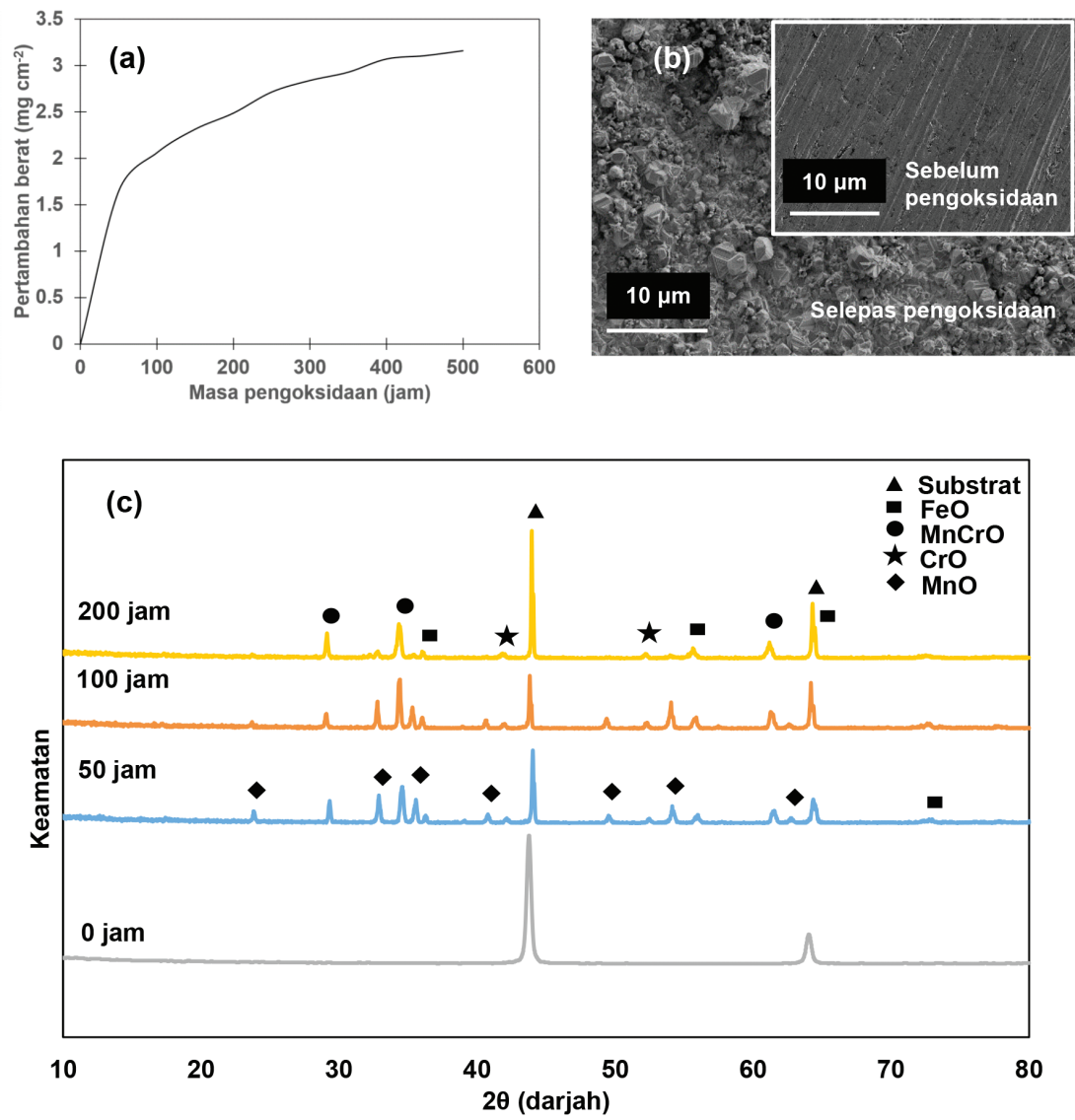

RAJAH 2. (a) Pertambahan berat sampel pada suhu $800^{\circ} \mathrm{C}$ dalam udara selama 500 jam dan (b) gambar FESEM mikrostruktur sisik oksida atas permukaan SUS430 selepas 200 jam serta (c) pola XRD sisik oksida yang terbentuk pada tempoh 50, 100 dan 200 jam

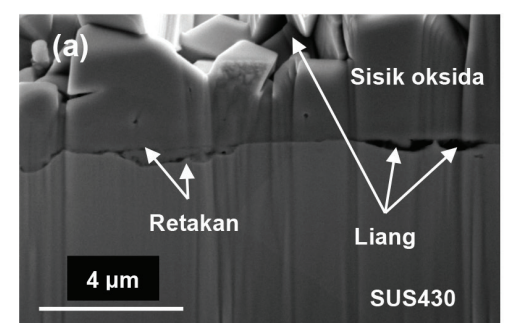

(b)
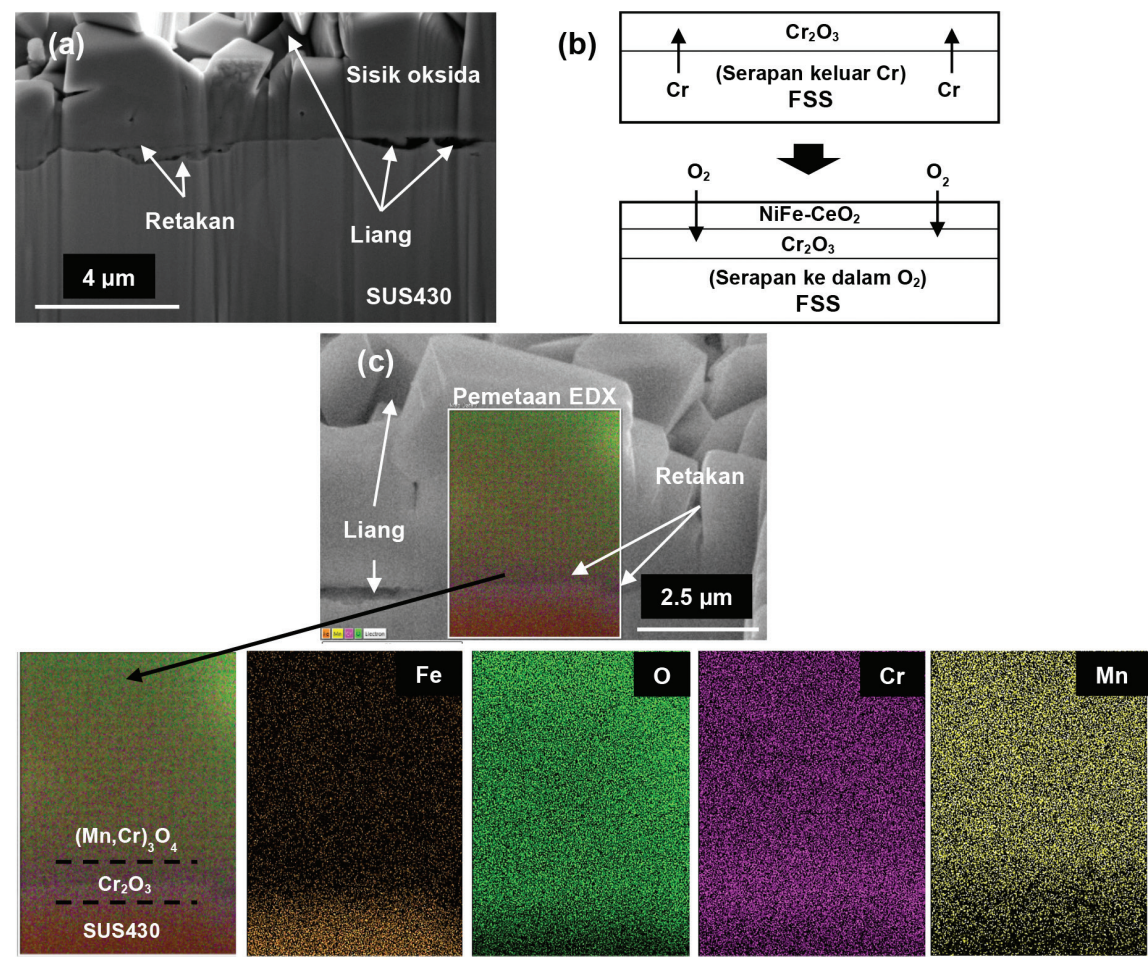

RAJAH 3. (a) Gambar FIB-FESEM sisik oksida, (b) perubahan mekanisme pertumbuhan sisik kromia dan (c) pemetaan EDX keratan rentas sisik oksida 
salutan seperti NiFe dengan bahan tambahan $\mathrm{CeO}_{2}$. Kajian mereka mendapati $\mathrm{CeO}_{2}$ bukan sahaja mengurangkan kadar pengoksidaan, malah mengubah mekanisme pertumbuhan kromia secara resapan keluar Cr kepada resapan ke dalam oksigen (Rajah 3(b)). Tambahan pula, $\mathrm{CeO}_{2}$ bertindak sebagai tapak penukleusan untuk liang, kemudiannya diisi oleh pertumbuhan sisik kromia secara ke dalam bagi menutupi liang tersebut.

Selain itu, keputusan EDX juga menunjukkan pembentukan sisik spinel $(\mathrm{Mn}, \mathrm{Cr})_{3} \mathrm{O}_{4}$ lebih dominan berbanding kromia $\mathrm{Cr}_{2} \mathrm{O}_{3}$ dengan kepekatan $\mathrm{Mn}$ yang tinggi pada bahagian atas sisik oksida (Rajah 3(c)). Pembentukan sisik spinel $(\mathrm{Mn}, \mathrm{Cr})_{3} \mathrm{O}_{4}$ yang cepat adalah kerana penyerapan ion $\mathrm{Mn}^{2+}$ melalui sisik kromia lebih pantas berbanding $\mathrm{Cr}^{3+}$ (Jo et al. 2015). Keputusan yang serupa dilaporkan oleh kajian Jiang et al. (2000). Mereka mendapati Mn yang terkandung dalam SUS430 diturunkan kepada spesies $\mathrm{Mn}$ bergas khususnya ion $\mathrm{Mn}^{2+}$ apabila terdedah kepada pengutuban katod. Spesies Mn bergas ini bertindak sebagai ejen penukleusan untuk pengendapan Cr. Tindak balas antara ion $\mathrm{Mn}^{2+}$ dengan spesies $\mathrm{Cr}_{2} \mathrm{O}_{3}$ bergas membentuk nuklei $\mathrm{Cr}-\mathrm{Mn}-\mathrm{O}$ dengan nuklei ini mempercepatkan penghabluran dan pertumbuhan bijian $\mathrm{Cr}_{2} \mathrm{O}_{3}$ dan diikuti oleh $(\mathrm{Mn}, \mathrm{Cr})_{3} \mathrm{O}_{4}$ dalam fasa pepejal. Proses ini boleh ditunjukkan dalam persamaan seperti berikut (Jiang et al. 2005, 2000):

$$
\begin{aligned}
& \mathrm{Mn}^{2+}+\mathrm{CrO}_{3(\mathrm{~g})} \rightarrow \mathrm{Cr}-\mathrm{Mn}-\mathrm{O}_{(\text {nuklei) }(\mathrm{p})} \\
& \mathrm{Cr}-\mathrm{Mn}-\mathrm{O}_{(\text {(nuklei) }(\mathrm{p})}+\mathrm{CrO}_{3(\mathrm{~g})} \rightarrow \mathrm{Cr}_{2} \mathrm{O}_{3(\mathrm{p})} \\
& \mathrm{Cr}-\mathrm{Mn}-\mathrm{O}_{(\text {nuklei)(p) }}+\mathrm{CrO}_{3(\mathrm{~g})}+\mathrm{Mn}^{2+} \rightarrow(\mathrm{Mn}, \mathrm{Cr})_{3} \mathrm{O}_{4(\mathrm{p})}
\end{aligned}
$$

Justeru, lapisan spinel $(\mathrm{Mn}, \mathrm{Cr})_{3} \mathrm{O}_{4}$ terbentuk di atas lapisan kromia $\mathrm{Cr}_{2} \mathrm{O}_{3}$ menjadikan ia lapisan oksida paling luar dan memenuhi permukaan SUS430 seperti yang ditunjukkan dalam Rajah 3(b). Dalam aplikasi antarahubung SFOP, lapisan spinel adalah digemari berbanding kromia kerana sifat rintangan elektrik dan pemeruapan $\mathrm{Cr}$ yang lebih rendah (Falk-Windisch et al. 2015).

\section{Perubahan Kekonduksian Elektrik Substrat Antarahubung} SUS430

Kekonduksian sampel SUS430 diukur selepas dioksidakan antara 10 jam hingga 200 jam pada suhu $800^{\circ} \mathrm{C}$ dalam udara persekitaran. Rajah 4 memaparkan nilai $\mathrm{R}_{\mathrm{s}}$ dan kekonduksian bahan SUS430 adalah stabil sepanjang tempoh 200 jam. Nilai $\mathrm{R}_{\mathrm{s}}$ bahan SUS430 bernilai $1.0 \times 10^{-3}$ $\Omega . \mathrm{cm}^{2}$ adalah kurang daripada nilai sasaran untuk bahan logam aloi iaitu $0.1 \Omega . \mathrm{cm}^{2}$ (Zeng et al. 2014). Selain itu, kekonduksian bahan SUS430 yang bernilai 10000 S.cm ${ }^{-1}$ adalah lebih tinggi daripada sasaran untuk kegunaan aplikasi SFOP iaitu 100 S.cm-1 (Zeng et al. 2007) yang menunjukkan bahan SUS430 sesuai untuk digunakan sebagai bahan antarahubung untuk aplikasi SFOP. Selain itu, keputusan ini juga menentusahkan kekonduksian elektrik lapisan sisik oksida kerana tiada perubahan ketara pada kekonduksian sampel berlaku sepanjang tempoh 200 jam uji kaji dijalankan.

Walau bagaimanapun, kajian seperti Yang et al. (2018) melaporkan bahawa nilai kekonduksian sisik oksida ini adalah rendah dan boleh membawa kepada degradasi sel SFOP. Pada ketebalan $9 \mu \mathrm{m}$, kekonduksian untuk lapisan spinel dan kromia masing-masing adalah

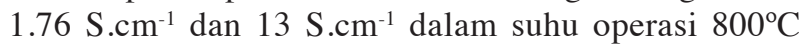
(Sakai et al. 2005), rendah daripada nilai sasaran yang diperlukan untuk aplikasi SFOP. Oleh itu, peningkatan ketebalan akan menjadikan sisik oksida sebagai perintang yang menurunkan kekonduksian elektrik (You et al. 2018). Tambahan pula, kajian Sakai et al. (2005) mendapati bahan FSS yang mempunyai elemen ferum (Fe) yang tinggi seperti ZMG232 membentuk lapisan spinel oksida yang terkandung $\mathrm{Fe}\left(\mathrm{MnCrFeO}_{4}\right)$ dan mempunyai kekonduksian yang tinggi iaitu 1830 S.cm ${ }^{-1}$ pada suhu $800^{\circ} \mathrm{C}$. Hal ini menjadikan bahan ini mempunyai kekonduksian elektrik yang lebih tinggi dan stabil berbanding SUS430 dalam tempoh pengoksidaan yang lama. Walaupun begitu, spinel $\left(\mathrm{MnCrFeO}_{4}\right)$ mempunyai serapan oksigen pantas yang tidak ideal
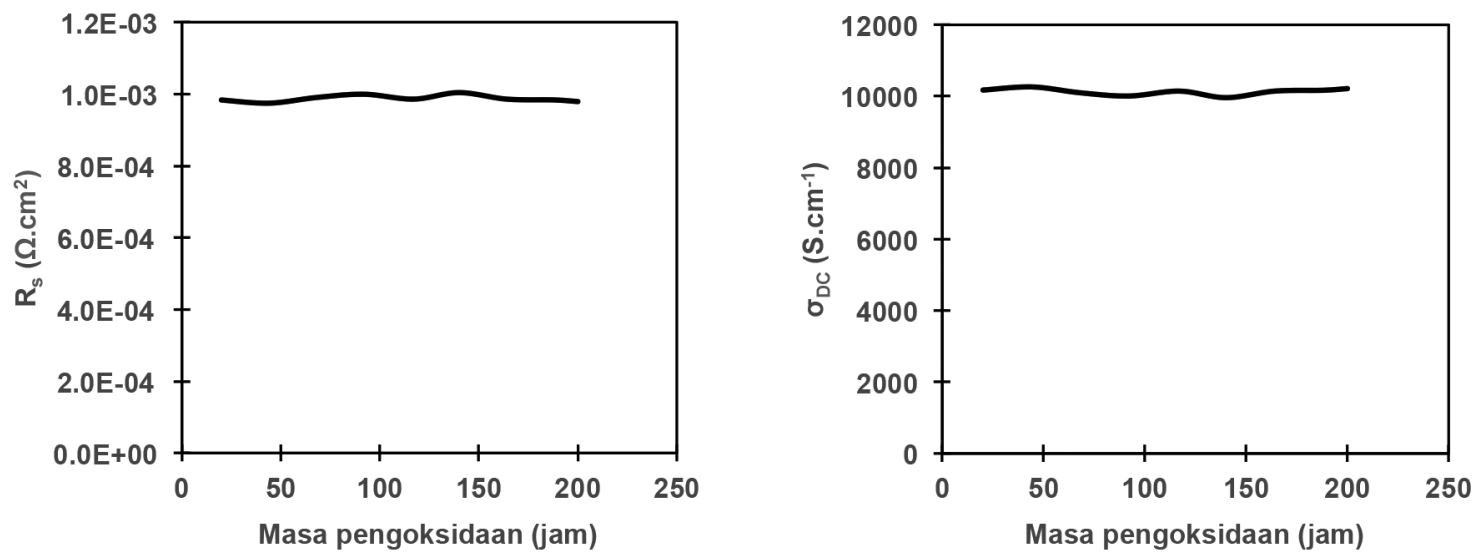

RAJAH 4. Nilai $\mathrm{R}_{\mathrm{s}}$ (a) dan kekonduksian (b) sampel SUS430 pada suhu $800^{\circ} \mathrm{C}$ dalam udara selama 200 jam 
kerana permukaannya yang dipenuhi liang dan cacatan lalu membawa kepada ketidakstabilan kimia.

\section{KESAN PEMERUAPAN CR KE ATAS PRESTASI KATOD LSCF}

\section{Pengendapan Cr ke Atas Katod LSCF}

Pengaruh pengendapan $\mathrm{Cr}$ dilihat memberi kesan signifikan ke atas permukaan katod LSCF. Rajah 5 memaparkan gambar FESEM permukaan katod sebelum dan selepas pendedahan kepada SUS430 selama 200 jam. Berdasarkan pemerhatian, berlaku pertumbuhan zarah yang halus dan hablur bersaiz besar dengan bentuk yang berbeza di sempadan dan tengahan bijian permukaan katod LSCF. Analisis XRD menunjukkan peningkatan puncak belauan yang tajam dan pembentukan beberapa puncak belauan kecil menandakan peningkatan bilangan hablur pada permukaan katod LSCF. Oleh itu, berkemungkinan besar hablur yang terbentuk adalah $\mathrm{SrCrO}_{4}$ dan $\mathrm{Cr}_{3} \mathrm{O}_{4}$ yang berkembang daripada zarah halus Cr. Keputusan ini selari dengan laporan Yokokawa et al. (2006) yang mendapati tarikan kimia lantanum kobaltit yang tinggi menyebabkan pembentukan utama $\mathrm{SrCrO}_{4}$ seperti yang ditunjukkan dalam persamaan berikut:

$$
\begin{aligned}
& \left(\mathrm{La}_{0.8} \mathrm{Sr}_{0.2}\right) \mathrm{CoO}_{3}+0.1 \mathrm{CrO}_{3}+0.050_{2} \rightarrow \\
& \left(\mathrm{La}_{0.8} \mathrm{Sr}_{0.1}\right) \mathrm{CoO}_{3}+0.1 \mathrm{SrCrO}_{4}
\end{aligned}
$$

Fenomena pembentukan zarah $\mathrm{SrCrO}_{4}$ dan $\mathrm{Cr}_{2} \mathrm{O}_{3}$ di atas permukaan katod LSCF telah diulas secara terperinci oleh Jiang dan Chen (2014)at SOFC operating temperatures, volatile $\mathrm{Cr}$ species are generated over the chromia scale, poisoning the cathodes such as ( $\mathrm{La}, \mathrm{Sr}$. Apabila terdedah pada suhu tinggi yang lama, berlaku penurunan kestabilan pada permukaan dan pengherotan struktur akibat daripada penamatan secara tiba-tiba struktur kekisi katod LSCF. Hal ini membawa kepada pembentukan segregasi $\mathrm{Sr}$ pada permukaan katod LSCF yang wujud dalam bentuk SrO dan $\mathrm{CoO}_{x}$ (Van Der Heide 2002). Segregasi ini khususnya SrO memainkan peranan penting dalam pengendapan $\mathrm{Cr}$ pada permukaan katod LSCF. SrO akan bertindak balas dengan spesies Cr bergas daripada lapisan sisik oksida pada bahan SUS430 lalu membentuk nuklei Cr-Sr-O pada permukaan katod LSCF, kemudiannya menghablur dan tumbuh bijian $\mathrm{SrCrO}_{4}$ dan/atau $\mathrm{Cr}_{2} \mathrm{O}_{3}$. Justeru, mekanisme pengendapan $\mathrm{Cr}$ pada permukaan katod LSCF boleh ditulis dengan persamaan berikut (Jiang et al. 2006):

$$
\begin{aligned}
& \mathrm{CrO}_{3(\mathrm{~g})}+\mathrm{SrO}_{(\mathrm{p})} \rightarrow \mathrm{Cr}-\mathrm{Sr}-\mathrm{O}_{(\text {nuklei)(p) }} \\
& \mathrm{Cr}-\mathrm{Sr}-\mathrm{O}_{(\text {nuklei)(p) }}+\mathrm{CrO}_{3(\mathrm{~g})} \rightarrow \mathrm{Cr}_{2} \mathrm{O}_{3(\mathrm{p})} \\
& \mathrm{Cr}-\mathrm{Mn}-\mathrm{O}_{(\text {nuklei)(p) }}+\mathrm{CrO}_{3(\mathrm{~g})}+\mathrm{SrO}_{(\mathrm{p})} \rightarrow \mathrm{SrCrO}_{4(\mathrm{p})}
\end{aligned}
$$
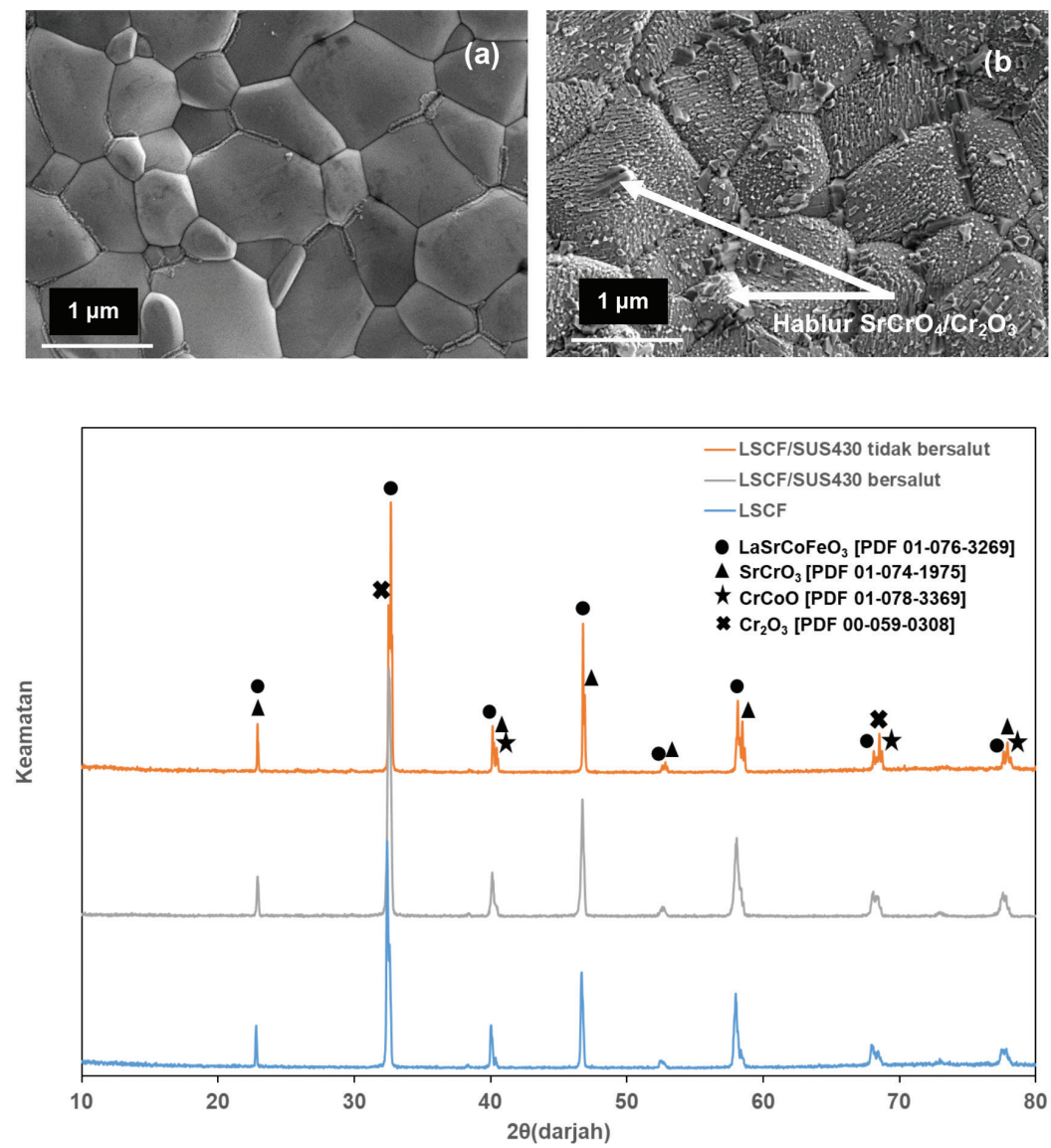

RAJAH 5. Keputusan FESEM permukaan katod LSCF sebelum (a) dan selepas (b) pengoksidaan selama 200 jam serta (c) pola XRD pembentukan hablur $\mathrm{SrCrO}_{4} / \mathrm{Cr}_{2} \mathrm{O}_{3}$ 
Selain melaporkan tentang peranan segregasi $\mathrm{SrO}$ dalam mempengaruhi mekanisme pengendapan $\mathrm{Cr}$, beberapa kajian lepas (Ardigò et al. 2011; Bentzen et al. 2009; Liu et al. 2012) turut berpendapat bahawa segregasi $\mathrm{CoO}_{\mathrm{x}}$ tidak begitu signifikan berbanding SrO. Namun, keputusan kajian ini menunjukkan bahawa pengendapan $\mathrm{Cr}$ pada segregasi $\mathrm{CrO}_{\mathrm{x}}$ boleh terjadi dengan kewujudan $\mathrm{CrCoO}_{3}$ seperti yang ditunjukkan dalam keputusan XRD. Justeru, menunjukkan segregasi $\mathrm{CrO}_{\mathrm{x}}$ juga signifikan dalam membantu pengendapan $\mathrm{Cr}$ pada permukaan katod LSCF.

\section{Perubahan Kekonduksian Elektrik dan Ionik Katod LSCF}

Kekonduksian katod yang bagus memaparkan keberkesanan pengaliran ion elektron melalui katod. Katod LSCF mempamerkan kelakuan kekonduksian campuran ionik-elektronik (MIEC) yang cemerlang pada suhu operasi SFOP sederhana $\left(600-800^{\circ} \mathrm{C}\right)$. Kelakuan MIEC yang bagus dapat membolehkan tindak balas penurunan oksigen yang pantas di seluruh permukaan katod termasuk pada antara muka katod/elektrolit dan sempadan tiga fasa (Sun et al. 2010). Rajah 6(a) menunjukkan kekonduksian elektrik katod LSCF sebagai fungsi masa sebelum dan selepas pendedahan kepada SUS430 selama 200 jam mempunyai arah aliran graf yang berbeza. Sampel LSCF yang belum didedahkan kepada SUS430 memaparkan peningkatan kekonduksian elektrik apabila suhu meningkat sehingga nilai maksimum iaitu $622{\mathrm{~S} . \mathrm{cm}^{-1}}^{-1}$ pada suhu $600^{\circ} \mathrm{C}$ dan kemudiannya menurun. Kelakuan kekonduksian elektrik ini telah dijangka bagi bahan semikonduktor dan katod jenis MIEC dengan kelakuan tersebut dipengaruhi oleh kekonduksian polaron kecil (Da Conceião et al. 2011; Xu et al. 2008). Peningkatan kekondusian elektrik menunjukkan kekonduksian polaron kecil semakin meningkat bersama suhu. Selain itu, penurunan kekonduksian elektrik selepas mencapai suhu tertentu adalah kerana peningkatan kepekatan kekosongan oksigen dalam sampel LSCF. Peningkatan kepekatan tersebut menunjukkan kandungan oksigen di dalam sampel semakin berkurang menyebabkan penurunan kepekatan pengangkut cas lubang elektron dan mengurangkan sumbangan elektronik kepada kekonduksian elektrik. Fenomena ini telah terbukti dan diperincikan dalam kajian Muhammad et al. (2018).

Namun, kelakuan kekonduksian LSCF berubah dan mempunyai nilai yang lebih rendah setelah didedahkan kepada SUS430. Keputusan ini telah dijangka kerana kecacatan yang berlaku pada pemukaan katod LSCF. Kecacatan ini dilihat memberi kesan signikan kepada aktiviti pemangkinan oksigen LSCF tersebut. Kekonduksian elektrik LSCF yang lebih rendah menunjukkan kepekatan kekosongan oksigen meningkat dengan mendadak apabila berlaku pengendapan gas $\mathrm{Cr}$ pada permukaan katod. Tindak balas yang berlaku antara gas $\mathrm{Cr}$ dan segregasi $\mathrm{SrO}$ dan $\mathrm{CoO}_{x}$ selepas pengendapan telah mempercepatkan pengurangan oksigen di dalam LSCF sekaligus menyebabkan kehilangan pengangkut cas lubang elektron dengan lebih pantas (Oh et al. 2009). Kehilangan pengangkut cas ini menjejaskan kekonduksian polaron kecil lalu mengurangkan kekonduksian elektrik LSCF.

Plot Arrhenius untuk $\log \left(\sigma_{\mathrm{DC}}\right)$ berlawanan suhu salingan $\left(1000 /\right.$ T.K $\left.^{-1}\right)$ telah diplot untuk kedua sampel LSCF seperti yang ditunjukkan dalam Rajah 6(b). Keduanya memaparkan kelakuan yang hampir linear pada suhu sederhana menandakan mekanisme loncatan polaron kecil mendominasi kekonduksian elektron dan boleh diungkap melalui persamaan Arrhenius seperti berikut:

$$
\sigma_{D C} T=A \exp \left(-\frac{E_{a}}{k T}\right)
$$

dengan $\mathrm{E}_{\mathrm{a}}$ adalah tenaga pengaktifan loncatan polaron kecil $(\mathrm{eV})$; $\mathrm{k}$ adalah pemalar Boltzmann $\left(8.617343 \times 10^{-5}\right.$ eV.K $\left.{ }^{-1}\right)$; T adalah suhu (K); A adalah faktor pra-eksponen; dan $\sigma_{\mathrm{DC}}$ adalah kekonduksian elektrikal arus terus (DC). Tenaga pengaktifan untuk kedua sampel telah dikira daripada padanan linear plot dalam lingkungan suhu $\left(700-300^{\circ} \mathrm{C}\right)$. Nilai tenaga pengaktifan yang telah dikira untuk sampel LSCF sebelum dan selepas pendedahan kepada Sus430 masing-masing adalah $0.067 \mathrm{eV}$ dan 0.093 eV. Peningkatan nilai tenaga pengaktifan membuktikan pertumbuhan yang berlaku pada permukaan LSCF akibat keracunan $\mathrm{Cr}$ bukan sahaja menurunkan kekonduksian elektrik, malah mempunyai sifat pemangkin tidak aktif yang membantutkan mekanisme loncatan polaron kecil.
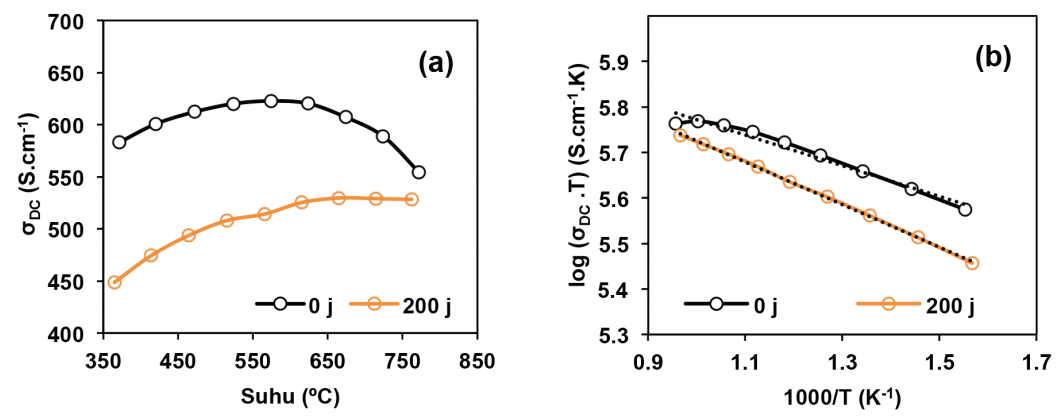

RAJAH 6. Kekondusian katod LSCF (a) dan plot Arhenius (b) sebelum dan selepas pendedahan kepada SUS430 selama 200 jam 
Walaupun keduanya memaparkan kekonduksian elektrik melebihi piawai yang diperlukan iaitu $100 \mathrm{~S} / \mathrm{cm}$ pada suhu $600^{\circ} \mathrm{C}$ (Zeng et al. 2007), keputusan ini menunjukkan prestasi LSCF boleh merudum apabila didedahkan kepada persekitaran spesis $\mathrm{Cr}$ bergas dalam jangka masa yang lebih lama.

\section{KESIMPULAN}

Bahan SUS430 adalah sesuai untuk digunakan sebagai bahan antarahubung kerana mempunyai rintangan pengoksidaan yang bagus dan pengaliran elektrik yang cemerlang. Namun, pertumbuhan pantas sisik oksida menjadi isu kerana menyumbang kepada pemeruapan spesies Cr bergas menyebabkan keracunan $\mathrm{Cr}$ pada katod LSCF. Pengendapan spesies $\mathrm{Cr}$ bergas pada permukaan katod LSCF membawa kepada pertumbuhan lapisan tidak aktif bermangkin yang mengandungi hablur spesies $\mathrm{SrCrO}_{4}$, $\mathrm{CrCoO}_{3}$ dan $\mathrm{Cr}_{2} \mathrm{O}_{3}$. Lapisan ini menyebabkan kawasan aktif katod terhalang menyebabkan kekonduksian elektrik merudum dan aktiviti pemangkinan seperti penurunan oksigen terbantut. Kajian masa hadapan untuk mengatasi masalah ini dengan penggunaan salutan pelindung akan dilakukan untuk meningkatkan rintangan pengoksidaan, pengaliran elektrik dan jangka hayat antarahubung serta penghadangan pemeruapan spesies $\mathrm{Cr}$ bergas.

\section{PENGHARGAAN}

Bantuan kewangan yang diberi oleh Universiti Kebangsaan Malaysia dan Kementerian Pengajian Tinggi Malaysia (GUP-2016-045) adalah sangat dihargai. Penulis juga ingin berterima kasih kepada Pusat Pengurusan Penyelidikan dan Instrumentasi Universiti Kebangsaan Malaysia (UKM) atas kemudahan alatan ujian yang cemerlang.

\section{RUJUKAN}

Anwar, M., Muhammed, A., Abdalla, A., Somalu, R. \& Muchtar, A. 2017. Effect of sintering temperature on the microstructure and ionic conductivity of $\mathrm{Ce}_{0.8} \mathrm{Sm}_{0.1} \mathrm{Ba}_{0.1} \mathrm{O}_{2-\delta}$ electrolyte. Processing and Application of Ceramics 11(1): 67-74.

Ardigò, M.R., Perron, A., Combemale, L., Heintz, O., Caboche, G. \& Chevalier, S. 2011. Interface reactivity study between $\mathrm{La}_{0.6} \mathrm{Sr}_{0.4} \mathrm{Co}_{0.2} \mathrm{Fe}_{0.8} \mathrm{O}_{3-\delta}$ (LSCF) cathode material and metallic interconnect for fuel cell. Journal of Power Sources 196(4): 2037-2045.

Baharuddin, N.A., Muchtar, A. \& Somalu, M.R. 2017. Short review on cobalt-free cathodes for solid oxide fuel cells. International Journal of Hydrogen Energy 42(14): 91499155.

Baharuddin, N.A., Rahman, H.A., Muchtar, A., Sulong, A.B. \& Abdullah, H. 2014. Kesan masa pengendapan dan saiz elektrod lawan dalam penghasilan katod komposit LSCFSDC karbonat untuk SOFC. Sains Malaysiana 43(4): 595601.

Bentzen, J.J., Høgh, J.V.T., Barfod, R. \& Hagen, A. 2009. Chromium poisoning of LSM/YSZ and LSCF/CGO composite cathodes. Fuel Cells 9(6): 823-832.
Brylewski, T., Kucza, W., Adamczyk, A., Kruk, A., Stygar, M., Bobruk, M. \& Dąbrowa, J. 2014. Microstructure and electrical properties of $\mathrm{Mn}_{1+\mathrm{x}} \mathrm{Co}_{2-\mathrm{x}} \mathrm{O}_{4}(0 \leq \mathrm{x} \leq 1.5)$ spinels synthesized using EDTA-gel processes. Ceramics International 40(9): 13873-13882.

Da Conceião, L., Silva, A.M., Ribeiro, N.F.P. \& Souza, M.M.V.M. 2011. Combustion synthesis of $\mathrm{La}_{0.7} \mathrm{Sr}_{0.3} \mathrm{Co}_{0.5} \mathrm{Fe}_{0.5} \mathrm{O}_{3}$ (LSCF) porous materials for application as cathode in IT-SOFC. Materials Research Bulletin 46(2): 308-314.

Falk-Windisch, H., Svensson, J.E. \& Froitzheim, J. 2015. The effect of temperature on chromium vaporization and oxide scale growth on interconnect steels for solid oxide fuel cells. Journal of Power Sources 287: 25-35.

Fergus, J.W. 2005. Metallic interconnects for solid oxide fuel cells. Materials Science and Engineering A 397(1-2): 271283.

Gan, L., Murakami, H. \& Saeki, I. 2018. High temperature oxidation of Co-W electroplated type 430 stainless steel for the interconnect of solid oxide fuel cells. Corrosion Science 134: $162-168$.

Hosseini, N., Abbasi, M.H., Karimzadeh, F. \& Choi, G.M. 2014. Development of $\mathrm{Cu}_{13} \mathrm{Mn}_{17} \mathrm{O}_{4}$ spinel coating on ferritic stainless steel for solid oxide fuel cell interconnects. Journal of Power Sources 273: 1073-1083.

Hosseini, N., Karimzadeh, F., Abbasi, M.H. \& Choi, G.M. 2016. Correlation between microstructure and electrical properties of $\mathrm{Cu}_{1.3} \mathrm{Mn}_{1.7} \mathrm{O}_{4}$ composite-coated ferritic stainless steel interconnects. Journal of Alloys and Compounds 673: 249-257.

Hua, B., Pu, J., Lu, F., Zhang, J., Chi, B. \& Jian, L. 2010. Development of a $\mathrm{Fe}-\mathrm{Cr}$ alloy for interconnect application in intermediate temperature solid oxide fuel cells. Journal of Power Sources 195(9): 2782-2788.

Irshad, M., Siraj, K., Raza, R., Ali, A., Tiwari, P., Zhu, B., Rafique, A.A.A., Muhammad Kaleem, U. \& Arslan, U. 2016. A brief description of high temperature solid oxide fuel cell's operation, materials, design, fabrication technologies and performance. Applied Sciences 6(3): 75.

Jiang, S.P. \& Chen, X. 2014. Chromium deposition and poisoning of cathodes of solid oxide fuel cells - A review. International Journal of Hydrogen Energy 39(1): 505-531.

Jiang, S.P., Zhen, Y.D., Zhang, S., Tok, A.I.Y. \& Wu, P. 2006. An electrochemical method to assess the chromium volatility of chromia-forming metallic interconnect for SOFCs. Journal of the Electrochemical Society 153(11): A2120.

Jiang, S.P., Zhang, S. \& Zhen, Y.D. 2005. Early interaction between $\mathrm{Fe}-\mathrm{Cr}$ alloy metallic interconnect and Sr-doped $\mathrm{LaMnO}_{3}$ cathodes of solid oxide fuel cells. Journal of Materials Research 20(3): 747-758.

Jiang, S.P., Zhang, J.P. \& Foger, K. 2000. Deposition of chromium species at $\mathrm{Sr}$-doped LaMnO [sub 3] electrodes in solid oxide fuel cells II. Effect on O[sub 2] reduction reaction. Journal of the Electrochemical Society 147(9): 3195.

Jo, K.H., Kim, J.H., Kim, K.M., Lee, I.S. \& Kim, S.J. 2015. Development of a new cost effective $\mathrm{Fe}-\mathrm{Cr}$ ferritic stainless steel for SOFC interconnect. International Journal of Hydrogen Energy 40(30): 9523-9529.

Linder, M., Hocker, T., Holzer, L., Friedrich, K.A., Iwanschitz, B., Mai, A. \& Schuler, J.A. 2013. $\mathrm{Cr}_{2} \mathrm{O}_{3}$ scale growth rates on metallic interconnectors derived from $40,000 \mathrm{~h}$ solid oxide fuel cell stack operation. Journal of Power Sources 243: 508-518.

Liu, M., Liu, M., Ding, D., Blinn, K., Li, X. \& Nie, L. 2012. Enhanced performance of LSCF cathode through surface 
modification. International Journal of Hydrogen Energy 37(10): 8613-8620.

Mah, J.C.W., Muchtar, A., Somalu, M.R., Ghazali, M.J. \& Raharjo, J. 2017. Formation of sol-gel derived (Cu,Mn,Co) 3 $\mathrm{O} 4$ spinel and its electrical properties. Ceramics International 43(10): 7641-7646.

Mahmud, L.S., Muchtar, A. \& Somalu, M.R. 2017. Challenges in fabricating planar solid oxide fuel cells: A review. Renewable and Sustainable Energy Reviews 72: 105-116.

Muhammed Ali, S.A., Anwar, M., Ashikin, N., Muchtar, A. \& Somalu, M.R. 2018. Influence of oxygen ion enrichment on optical, mechanical, and electrical properties of LSCF perovskite nanocomposite. Ceramics International 44(9): 10433-10442.

Muhammed, M.A., Anwar, M., Raduwan, N.F., Muchtar, A. \& Somalu, M.R. 2018. Optical, mechanical and electrical properties of LSCF-SDC composite cathode prepared by solgel assisted rotary evaporation technique. Journal of Sol-Gel Science and Technology 86(2): 1-12.

Oh, D., Armstrong, E., Jung, D., Kan, C. \& Wachsman, E. 2009. Mechanistic understanding of $\mathrm{Cr}$ poisoning on $\mathrm{La}_{0.6} \mathrm{Sr}_{0.4} \mathrm{Co}_{0.2} \mathrm{Fe}_{0.8} \mathrm{O}_{3-\delta}$ (LSCF). ECS Transactions 25(2): 2871-2879.

Qi, Q., Liu, Y. \& Huang, Z. 2015. Promising metal matrix composites (TiC/Ni-Cr) for intermediate-temperature solid oxide fuel cell (SOFC) interconnect applications. Scripta Materialia 109: 56-60.

Raharjo, J., Muchtar, A., Daud, W.R.W., Muhamad, N. \& Majlan, E.H. 2012. Physical and thermal characterisations of $\mathrm{SDC}-(\mathrm{Li} / \mathrm{Na}) 2 \mathrm{CO} 3$ electrolyte ceramic composites. Sains Malaysiana 41(1): 95-102.

Rahman, H.A., Muchtar, A., Muhamad, N. \& Abdullah, H. 2010. Komposit $\mathrm{La}_{1-\mathrm{x}} \mathrm{Sr}_{\mathrm{x}} \mathrm{Co}_{1-\mathrm{y}} \mathrm{Fe}_{\mathrm{y}} \mathrm{O}_{3-\delta}$ ( LSCF ) sebagai bahan katod tahan lama bagi sel fuel oksida pejal bersuhu sederhanarendah: Ulasan kajian. Jurnal Kejuruteraan 22: 1-9.

Ranjbar-Nouri, Z., Soltanieh, M. \& Rastegari, S. 2018. Applying the protective $\mathrm{CuMn}_{2} \mathrm{O}_{4}$ spinel coating on AISI-430 ferritic stainless steel used as solid oxide fuel cell interconnects. Surface and Coatings Technology 334: 365-372.

Sachitanand, R., Sattari, M., Svensson, J.E. \& Froitzheim, J. 2013. Evaluation of the oxidation and $\mathrm{Cr}$ evaporation properties of selected $\mathrm{FeCr}$ alloys used as SOFC interconnects. International Journal of Hydrogen Energy 38(35): 1532815334.

Sakai, N., Horita, T., Xiong, Y.P., Yamaji, K., Kishimoto, H., Brito, M.E., Yokokawa, H. \& Maruyama, T. 2005. Structure and transport property of manganese-chromium-iron oxide as a main compound in oxide scales of alloy interconnects for SOFCs. Solid State Ionics 176(7-8): 681-686.

Shaigan, N., Qu, W., Ivey, D.G. \& Chen, W. 2010. A review of recent progress in coatings, surface modifications and alloy developments for solid oxide fuel cell ferritic stainless steel interconnects. Journal of Power Sources 195(6): 1529-1542.

Sun, C., Hui, R. \& Roller, J. 2010. Cathode materials for solid oxide fuel cells: A review. Journal of Solid State Electrochemistry 14(7): 1125-1144.

Tucker, M.C., Kurokawa, H., Jacobson, C.P., De Jonghe, L.C. \& Visco, S.J. 2006. A fundamental study of chromium deposition on solid oxide fuel cell cathode materials. Journal of Power Sources 160(1): 130-138.
Van Der Heide, P.A.W. 2002. Systematic x-ray photoelectron spectroscopic study of $\mathrm{La}_{1-\mathrm{x}} \mathrm{Sr}_{\mathrm{x}}$-based perovskite-type oxides. Surface and Interface Analysis 33(5): 414-425.

Van Herle, J., McEvoy, A.J. \& Thampi, K.R. 1994. Conductivity measurements of various yttria-stabilized zirconia samples. Journal of Materials Science 29(14): 3691-3701.

Wu, J. \& Liu, X. 2010. Recent development of SOFC metallic interconnect. Journal of Materials Science and Technology 26(4): 293-305.

Xu, Q., Huang, D.P., Zhang, F., Chen, W., Chen, M. \& Liu, H.X. 2008. Structure, electrical conducting and thermal expansion properties of $\mathrm{La}_{0.6} \mathrm{Sr}_{0.4} \mathrm{Co}_{0.8} \mathrm{Fe}_{0.2} \mathrm{O}_{3-\delta}-\mathrm{Ce}_{0.8} \mathrm{Sm}_{0.2} \mathrm{O}_{2-\delta}$ composite cathodes. Journal of Alloys and Compounds 454(1-2): 460465.

Yang, J.J., Yan, D., Huang, W., Li, J., Pu, J., Chi, B. \& Jian, L. 2018. Improvement on durability and thermal cycle performance for solid oxide fuel cell stack with external manifold structure. Energy 149: 903-913.

Yokokawa, H., Horita, T., Sakai, N., Yamaji, K., Brito, M.E., Xiong, Y.P. \& Kishimoto, H. 2006. Thermodynamic considerations on $\mathrm{Cr}$ poisoning in SOFC cathodes. Solid State Ionics 177(35-36): 3193-3198.

You, P.F., Zhang, X., Zhang, H.L., Liu, H.J. \& Zeng, C.L. 2018. Effect of $\mathrm{CeO}_{2}$ on oxidation and electrical behaviors of ferritic stainless steel interconnects with $\mathrm{Ni} F e$ coatings. International Journal of Hydrogen Energy 43(12): 7492-7500.

Zeng, Y., Wu, J., Baker, A.P. \& Liu, X. 2014. Magnetron-sputtered $\mathrm{Mn} / \mathrm{Co}(40: 60)$ coating on ferritic stainless steel SUS430 for solid oxide fuel cell interconnect applications. International Journal of Hydrogen Energy 39(28): 16061-16066.

Zeng, P., Ran, R., Chen, Z., Gu, H., Shao, Z., da Costa, J.C.D. \& Liu, S. 2007. Significant effects of sintering temperature on the performance of $\mathrm{La}_{0.6} \mathrm{Sr}_{0.4} \mathrm{Co}_{0.2} \mathrm{Fe}_{0.8} \mathrm{O}_{3-\delta}$ oxygen selective membranes. Journal of Membrane Science 302(1-2): 171179.

Zhu, W.Z. \& Deevi, S.C. 2003. Opportunity of metallic interconnects for solid oxide fuel cells: A status on contact resistance. Materials Research Bulletin 38(6): 957-972.

Isyraf Aznam, Joelle Mah Chia Wen, Andanastuti Muchtar*, Nurul Akidah Baharuddin \& Mahendra Rao Somalu Institut Sel Fuel

Universiti Kebangsaan Malaysia

43600 UKM Bangi, Selangor Darul Ehsan

Malaysia

Andanastuti Muchtar* \& Mariyam Jameelah Ghazali

Pusat Kejuruteraan Bahan dan Pembuatan Pintar

Fakulti Kejuruteraan dan Alam Bina

Universiti Kebangsaan Malaysia

43600 UKM Bangi, Selangor Darul Ehsan

Malaysia

*Pengarang untuk surat-menyurat; email: muchtar@ukm.edu.my

Diserahkan: 7 November 2018

Diterima: 14 Februari 2019 